\title{
The Moderating Effect of Firm Size on the Relationship Between Capital Structure and Financial Distress of Non-Financial Companies Listed in Kenya
}

\author{
Robert Gitau Muigai ${ }^{1,}$, , Jane Gathigia Muriithi' ${ }^{2}$ \\ ${ }^{1}$ Department of Finance and Accounting, School of Business and Economics, Kirinyaga University, Nairobi, Kenya \\ ${ }^{2}$ Department of Economics, Accounting and Finance, School of Business, Jomo Kenyatta University of Agriculture and Technology, Nairobi, \\ Kenya
}

\author{
Email address: \\ gitauwamuigai@yahoo.com (R. G. Muigai) \\ ${ }^{*}$ Corresponding author
}

\section{To cite this article:}

Robert Gitau Muigai, Jane Gathigia Muriithi. The Moderating Effect of Firm Size on the Relationship Between Capital Structure and Financial Distress of Non-Financial Companies Listed in Kenya. Journal of Finance and Accounting. Vol. 5, No. 4, 2017 , pp. 151-158. doi: $10.11648 /$ j.jfa.20170504.15

Received: April 28, 2017; Accepted: May 10, 2017; Published: June 23, 2017

\begin{abstract}
This paper sought to establish the moderating effect of firm size on the relationship between capital structure and financial distress of listed non-financial firms in Kenya. Firm size was measured using the natural logarithm of total assets while capital structure was operationalized by total debt, long-term debt and short term debt financing. The degree of financial distress was measured using the Altman's Z-score index as reviewed for the emerging markets. Secondary data from audited and published financial statements was collected on the 40 listed non-financial firms between year 2006 and 2015 . The study estimated the specified panel regression model for fixed effects as supported by the Hausman test results. Feasible Generalized Least Squares (FGLS) regression results revealed that firm size has a significant moderating effect on the relationship between capital structure and financial distress of non-financial firms. Specifically, the study found that although generally debt has a negative and significant effect on financial distress of the studied companies, this effect becomes positive and significant as the size of the firm increases. The study further found that use of long term debt has a positive and significant effect among largescale firms while short term debt is significantly detrimental. On the basis of these empirical findings, the study recommended that managers of listed non-financial companies should always consider the size of the firm in making leverage choice decisions for their entities.
\end{abstract}

Keywords: Capital Structure, Financial Distress, Firm Size

\section{Introduction}

Financial distress is a common phenomenon within the corporate sector in many countries. According to Andrade and Kaplan (1998), financial distress is a situation where a firm is unable to meet the financial obligations as they become due or does so with difficulties. The net effect is that the survival of financially struggling corporations is significantly compromised and in extreme cases may result in bankruptcy. According to Mwangi, Muathe, and Kosimbei (2014) such an eventuality does not only erode investors' confidence on the capital market but also culminate in loss of shareholders' wealth.
Empirical research in this domain has attributed corporate financial distress to varied factors such as inept corporate governance, severe competition for markets and factors of production as well as adverse economic performance (Outecheva, 2007). Besides these factors, literature on financial distress prediction has identified capital structure as a significant determinant of corporate financial distress (Altman, 2000; Ohlson, 1980). Capital structure is defined as the manner in which firms employ one form of financing in place of the other with regard to the dichotomous sources of debt and equity (Pandey, 2009). According to Baimwera and Muriuki (2014), high degree of financial leverage inadvertently expose corporations to higher levels of 
financial risk which often result in financial distress. Further, Muigai (2016) observed that excessive employment of debt capital to finance corporate operations has a negative and significant effect on financial distress of non-financial firms listed in Kenya. Similar studies undertaken within the Asian economies have provided parallel conclusions (Chen, 2004; Gupta, Srivastava, \& Sharma, 2014).

A review of literature on corporate financing has nonetheless postulated firm size as a key determinant of financing structure. Specifically, firm size which refers to the production and turnover capacities possessed by a firm (Surajit \& Saxena, 2009); has been shown to be positively associated to corporate gearing levels. In undertaking these studies, the natural logarithm of total assets and turnover has been used to measure firm size. Researchers have attributed this relationship to the fact that lenders often perceive larger firms as less risky consumers of credit because of their superior collateral structure (Maina \& Ishmail, 2014; Mule, Mukras, \& Nzioka, 2015). This is in contrast to smaller entities that apparently possess inferior tangibility and therefore suffer from credit rationing. Considering the advantage enjoyed by larger firms in accessing credit, they are hypothetically expected to perform better and hence be less distressed compared to smaller firms.

In the light of this trend, this study is aimed at investigating the moderating effect of firm size on the relationship between capital structure and financial distress of non-financial firms listed in Kenya. Essentially, the study is predicated on establishing whether or not listed nonfinancial firms exhibit similar financial distress patterns depending on the way they are financed, regardless of their sizes. The study measured capital structure using the ratios of total debt to total capital as well as the proportions of long term and short term debt in aggregate gearing levels. In addition, the study adopted the natural logarithm of total assets as a measure of firm size while the Altman's Z-score of financial distress as reviewed for emerging markets was used to proxy the degree of financial distress.

\section{Literature Review}

The underlying theoretical basis for arguing that firm size is related to corporate financial distress can be found in the traditional neoclassical view of the firm and the concept of economies of scale. According to Papadogonas (2006), Economies of scale occurs when a large firm negotiates for better interest rates or better discounts and rebates due to a large quantity that it buys. Further, he opined that specialization and division of labor as well as division of high fixed costs across large production volumes may often give rise to economies of scale. In line with this concept, the author postulated that large firms are generally financially robust. On the contrary, an alternative conceptual framework that postulate a negative relationship between firm size and corporate financial distress exists. This school of thought posits that large firms may come under the control of managers interested in pursuing self-serving goals at the expense of profit maximization objective; hence resulting to sub-optimal performance (Marsh, 1982).

Finance scholars such as Gonenc (2005) and Dittmar (2004) have found that large firms may have a tendency to issue more debt due to their high tangibility; which may result to negative effects of overleveraging leading financial distress. This position was also supported by Khan (2012) and Maina and Ishmail (2014) whose studies found a negative relationship between firm size and firm value as measured through their Tobin's Q. The authors argued that large firms are often inefficient in their operations resulting to dismal financial performance.

Amato and Burson (2007) Studied the relationship between firm size and financial distress of the corporations operating in the UK's financial services sector. In their study that tested for both linear and cubic form of the relationship, they found that a negative relationship existed between firm size and financial distress under both linear and cubic models. They contended that as firms expand, they had the tendency to increase the debt component in the capital structure as opposed to small-sized firms. This tendency inevitably resulted to reduction in efficiency which culminates in higher levels of financial distress. In a related study, Serrasqueiro and Nunes (2008) studied the effects of firm size on financial performance among the SMEs operating in manufacturing sector in Portugal. The study that covered 5 years (2002 to 2007) showed a negative and statistically significant relationships between the natural logarithms of total assets, total sales and number of employees of the firms (size) and their financial distress measures. They attributed the negative relationship to a system of capital structuring where large-sized firms employed more debt capital to finance their assets as a result of their superior collateralization; which resulted to decline in performance levels.

Lee (2009) Examined the role played by firm size in determining the financial distress of the US publicly -held firms. By using the fixed effect dynamic panel data model and a sample of more than 7000 entities, the study showed that absolute firm size (total assets) had a significant nonlinear relationship with financial distress. This meant that larger firms were more likely to experience financial distress in comparison to smaller firms. The study attributed the negative coefficient between the variables to the tendency by larger firms to finance their assets by large amount of debt capital due to increased borrowing capacity. Similar findings were echoed by the study carried out by Artikis, Eriotis, Vasiliou, and Ventoura-Neokosmidi (2007) on 129 Greek companies listed on the Athens Stock Exchange during 19972001. The study showed a negative and statistically significant relationship between firm size and value of the firm as measured by Tobin's Q. The adverse empirical relationship was attributed to the observation that big firms gravitated towards use of more indebtedness than smaller firms and hence were vulnerable to risks of financial distress.

Central to the above general positions is the fact that as a firm grows in size, its ability to borrow increases, and so, its 
debt-equity ratio increases concurrently. This exposes the larger firms to risk of bankruptcy leading to increase in overall cost of capital. Within the circuit of small firms, need for funds may be limited by the fact that their scales of operations are also limited. Consequently, not only would banks and investors alike be afraid of committing funds in the projects of small businesses, the small firms themselves may be indisposed to exposing themselves to risks associated with distress and bankruptcy, as well as loss of ownership.

Ozgulbas, Koyuncugil, and Yilmaz (2006) On the other hand studied the effect of firm size on performance over the firms operating in Istanbul Stock Exchange between the years of 2000 to 2005 . The study revealed that big scale firms were less distressed as compared to small scale firms. The researcher attributed this dichotomy in financial distress levels of the firms to the fact that banks were more willing to lend their funds to larger firms partly because they are more diversified and partly because larger firms usually request larger amounts of debt capital than smaller firms. The researcher argued that larger firms were able to reduce transaction costs associated with debt issuance and could arrange a lower interest rate. The findings were in consonance with those by Mule et al. (2015) whose study of listed firms in Kenya during the period 2010 - 2014 showed a positive and significant relationship between firm size (logarithm of total sales) and financial distress. The authors observed that higher profitability for larger firms as compared to smaller firms could be attributed to differential in debt structure of the two categories of the firms and the ability of larger firms to harness the advantages associated with financial leverage.

In a study that sampled 15 companies operating in South India, Vijayakumar and Tamizhselvan (2010) used a simple semi-logarithmic specification of the model to determine the relationship between firm size and financial performance. The authors used natural logarithm of sales and total assets as measures of size and profit margin as well as profit to total assets as measures of financial performance. The study found a positive and significant relationship between the two variables. In conclusion, the authors attributed the positive relationship to the fact that large firms had the ability to arrange for debt at discounted interest rates as well as refinance long term debt hence enjoy sustained liquidity to finance the capital projects. The findings mirrored those by Velnampy and Nimalathasan (2010) who conducted a study on the relationship between firm size and probability of financial distress of all the commercial banks in Sri Lanka over the period of 10 years from 1997 to 2006. The authors observed a negative relationship between bank size and the probability of bank failure; implying that big banks showed no signs of bankruptcy as was the case on small-sized banks. This result was attributed to the fact that larger banks were more diversified and thus bore lower probability of default.

In a similar fashion, Jónsson (2008) studied the relationship between financial distress and size of the firms operating in Iceland. The logarithm of total sales was used to measure firm size while return on equity represented financial distress level. After controlling for firm age, the results of the analysis showed that bigger firms have higher profitability as compared to smaller firms. The author observed that though large firms had higher levels of debt financing as compared to smaller firms, they were able to negotiate lower interest rates on debts; which resulted to improved financial distress. These results were in agreement with those by Babalola (2013) whose study of 80 Nigerian manufacturing firms listed in the Nigerian stocks exchange showed a positive and significant relationship between firm size and profitability (ROA).

The review of empirical literature on how firm size influences financial distress has produced mixed results and is therefore not clear. While some studies have shown that larger firms are more likely to suffer financial distress due to their high appetite for debt financing and inefficiencies, other studies have postulated that it is the smaller firms that are susceptible to financial distress due to their inability to access credit. Further, it has been argued that factors such as economies of scale could mitigate the effects of financial distress among large-scale firms in contrast from smaller ones. It is on the background of these conflicting findings that this study is set forth.

\section{Methodology}

\subsection{Research Design}

The study employed panel quantitative research design. This research design was preferred because the data used in the study comprise of ratios that have been transformed into panels. The research design is suitable in studies where both the cross-sectional and longitudinal characteristics of the units being studied are required (Gujarati, 2003).

\subsection{Study Population}

The population of the study comprised all the nonfinancial companies listed in Kenya's Nairobi Securities Exchange during the 10 years period to December 2015. In total, 40 non-financial firms were enlisted in the NSE. According to Mugenda and Mugenda (2003), a census is preferred where the population is small and manageable. Further, census method enhances validity of the collected data by eliminating errors associated with sampling (Saunders, Lewis, \& Thornhill, 2009). The study omitted firms listed within the banking and insurance sectors since they are associated with tight regulations with regard to capital holding and liquidity operations. As observed by Mwangi et al. (2014), this heterogeneity makes it difficult to make it difficult to conduct hypothesis testing for the study.

\subsection{Data Collection}

The study used secondary data that was extracted from audited financial statements and annual reports of individual non-financial firms during the ten years period (2006 2015). The data obtained for all variables in each firm was organized in panels. According to Baltagi, Bratberg, and 
Holmås (2005) Panel data is suitable for longitudinal analysis because it provides both the time and cross-sections dimensions.

\subsection{Data Analysis}

The relevant data was transformed into ratios for the study variables in each firm for every year using excel program. Descriptive statistics such as measures of central tendency and measures of dispersion were used to summarize and profile the pattern in each firm. In addition, panel regression analysis using Stata Version 11 was employed to establish the nature and significance of the relationship between independent variables and dependent variable. Significance of individual explanatory variable on the dependent variable was carried out using t-test at 5\% significance level. Joint significance of the regression model was performed by means of F-test.

\subsection{Measurement of Study Variables}

The table below shows how the variables used in the study were measured and operationalized

Table 1. Measurement of Study Variables.

\begin{tabular}{lll}
\hline Variables & Measurements & Notation \\
\hline $\begin{array}{l}\text { Independent Variables } \\
\text { Financial Leverage }\end{array}$ & Total debt/Total capital & TD \\
$\begin{array}{l}\text { Long term debt } \\
\text { Short term debt }\end{array}$ & Total Non-current liabilities/Total debt & LTD \\
$\begin{array}{l}\text { Moderating Variable } \\
\text { Firm Size }\end{array}$ & Total Current liabilities/Total debt & STD \\
$\begin{array}{l}\text { Dependent Variable } \\
\text { Financial Distress }\end{array}$ & Natural Logarithm of total assets & SZ \\
\hline
\end{tabular}

$Z$ - score $=3.25+6.56 x_{1}+3.26 x_{2}+6.72 x_{3}+1.05 x_{4}$

Where:

$\mathrm{Z}=$ Financial distress index (emerging market score),

$\mathrm{X}_{1}=$ Net working capital/Total assets,

$\mathrm{X}_{2}=$ Retained earnings/Total assets,

$\mathrm{X}_{3}=$ Earnings before Interest and Taxes/Total Assets,

$\mathrm{X}_{4}=$ Book value of equity/Book value of total liabilities

Zones of discrimination: $Z>5.85$ : Safe zone, $4.15<Z<5.85$ : Gray zone, $Z<4.15$ : Distress zone.

Source: Altman \& Hotchkiss (2006, pp. 267-8)

\subsection{Empirical Model Specification}

The study estimated the following two panel regression models to determine both the primary and moderating effects of firm size. Equation 1 was used to estimate the main effects of capital structure while Equation 2 estimated the moderating (interaction) effects of firm size in the capital structure.

$$
\begin{gathered}
F S_{i t}=\beta_{0}+\sum_{i=1}^{3} \beta_{i} X_{i}+\mu_{i t} \\
F S_{i t}=\beta_{0}+\sum_{i=1}^{3} \beta_{i} X_{i t}+\sum_{i=1}^{3} \theta_{i}\left(X_{i t} * S Z_{i t}\right)+\mu_{i t}
\end{gathered}
$$

Where: $F S_{i t}$ is the degree of financial distress, $\beta_{0}$ is the intercept term, $\beta_{i}$ are the positive or negative coefficients of the explanatory variables, $\theta_{i}$ are the coefficients of the moderating variables, $X_{i t}$ is a vector of explanatory variables and $\mu_{i t}$ is the error term (the time-varying disturbance term is serially uncorrelated with mean zero and constant variance).

\section{Results and Discussions}

\subsection{Descriptive Statistics}

Table 2 shows that on average, non-financial firms had a financial distress index of 7.85; which indicates a relatively financially sound crop of firms. The standard deviation of 3.008 indicates a high variability on the degree of financial distress among firms. This is confirmed by the wide range between the maximum and minimum Z-score of 19.423 and 1.512 respectively. The results further shows that nonfinancial firms employed $45 \%$ debt capital on average to finance their assets. This indicates a modest gearing position by the firms with a relatively low variability. This could be attributed to the high cost of borrowing as a result of prevailing high interest rates in Kenya.

\begin{tabular}{|c|c|c|c|c|c|c|c|c|}
\hline Variables & Mean & Std. Dev. & Median & Max & Min & Skewness & Kurtosis & Count \\
\hline Z-score & 7.851 & 3.008 & 7.445 & 19.423 & -1.512 & 0.825 & 4.797 & 367 \\
\hline Total debt & 0.451 & 0.171 & 0.441 & 0.882 & 0.068 & 0.090 & 2.211 & 367 \\
\hline Long term debt & 0.396 & 0.284 & 0.361 & 0.964 & 0.000 & 0.207 & 1.694 & 367 \\
\hline Short term debt & 0.604 & 0.284 & 0.639 & 1.000 & 0.036 & -0.207 & 1.694 & 367 \\
\hline Firm Size & 15.333 & 1.685 & 15.207 & 19.056 & 10.956 & -0.024 & 2.707 & 367 \\
\hline
\end{tabular}

Table 2. Summary statistics. 
The results further indicate that during the period of study, the firms had approximately $39.6 \%$ of their debt portfolio made up of non-current debt with $60.4 \%$ constituting current debt. This implies a higher preference for short term debt as opposed to long term debt. This could be attributed to the fact that short term debt is more easily accessible owing to low collateral requirements (Maina \& Ishmail, 2014).

Table 2 also indicates that listed non-financial firms held an average of Kshs 4.5 billion worth of total assets; with a minimum of 57.2 million and a maximum of Kshs 188.7 billion. This signifies that the firms were relatively large. Both the Skewness and Kurtosis shows that the data on all variables was nearly normally distributed (at 0 and 3) respectively and hence suitable for further statistical analysis.

\subsection{Panel data Diagnostic Tests}

To determine the suitability of the panel data for statistical analysis, various tests were carried out on the data collected. The tests that aimed at establishing if the panel data fulfilled the cardinal requirements of classical linear regression analysis included: panel unit root test, test for multicollinearity among independent variables panel-level heteroscedasticity test and serial correlation test. Where violation to these assumptions was detected, appropriate remedies were employed.

\subsubsection{Panel Unit Root Test}

Panel unit root test was applied on all variables used in the analysis in order to determine whether or not the panel data was stationary. This involved solving for the value of $\rho$ in the general equation:

$$
Y_{i t}=\alpha+\rho Y_{i t-1} \pm \mu_{i t}
$$

Where: $\mathrm{t}=1 \ldots .10$ years and $\mathrm{i}=40$ firms

If $\rho=1$, it implied that the observation $Y_{\text {it }}$ was dependent on its lag value $\mathrm{Yi}_{\mathrm{t}-1}$ and hence the data was non-stationary. The converse would be true if $\rho<1$. The necessity of this procedure was to avoid a situation where the obtained regression results were spurious; hence jeopardizing testing of hypothesis (Granger \& Newbold, 1974). The study applied Fisher-type test (with trend) because it has more advantages than other panel unit root tests. The Fisher-type unit root test requires specification of Dickey-Fuller to test whether a variable has unit root.

Table 3. Fisher-type (with time trend) unit root test results.

\begin{tabular}{lll}
\hline Variable & Statistic & P-value \\
\hline Total debt & 185.9272 & 0.0000 \\
Long term debt & 176.2539 & 0.0000 \\
Short term debt & 159.9525 & 0.0000 \\
Firm Size & 125.9606 & 0.0008 \\
Financial Distress & 230.8624 & 0.0000 \\
\hline
\end{tabular}

$\mathrm{H}_{0}$ : All panels contain unit roots; Significance level: $5 \%$

Based on the results displayed in Table 3, the study rejected the Null hypothesis that the panel data contained unit roots at 5\% significance level. Effectively, the study concluded that all the variables used by the study did not have unit root and were therefore were used in levels instead of their first difference.

\subsubsection{Panel-Level Heterescedasticity Test}

To test for panel level heteroscedasticity, the study adopted Breusch-Pagan/Cook-Weisberg test for heteroscedasticity. This involved first estimating the specified empirical model by OLS and then running the test against the null hypothesis of homoscedastic (constant) error variance (Torres-Reyna, 2007). The tests results provided a chi-square distribution value of 26.55 with a corresponding p-value of 0.0000 . The results signifies that the chi-square statistic was significant at 5 percent level and hence the null hypothesis of constant variance was rejected. This indicated presence of panel-level heteroscedasticity in the study data as recommended by (Wiggins \& Poi, 2001). To correct this violation of classical linear regression assumptions, the study employed the feasible generalized least squares (FGLS) estimation technique instead of the ordinary least squares method.

\subsubsection{Serial Correlation Test}

To detect autocorrelation in panel data, the study used Wooldridge test for autocorrelation against the null hypothesis that there was no first order autocorrelation. The test results provided F-statistic value of 20.174 at 1 and 38 degrees of freedom. The F-statistic value had a corresponding p-value of 0.0001 indicating that the null hypothesis of no first order autocorrelation was strongly rejected at 5\% significance level. The result therefore concluded that the panel data suffered from the problem of first-order autocorrelation. The study remedied this violation of classical linear regression model assumption by employing FGLS estimation technique (Mwangi et al., 2014).

\subsubsection{Test for Multicollinearity}

Pair-wise correlation was used to examine the level of collinearity present between explanatory variables used in the study. Ordinarily, severe multicollinearity would be exhibited between the primary and their corresponding moderated variables; e.g. between total debt (TD) variable and total debt moderated by size (TD*SZ). This undesirable phenomenon makes it very difficult to distinguish the unique contributions of individual predictors on the variance of the dependent variable. High correlations among predictors also makes the standard errors of the estimated coefficients large hence compromising inferential estimation. To deal with this multicollinearity problem between primary and moderated variables, the study adopted variable centering approach. The procedure involves transforming the variable by subtracting the sample mean prior to computing the product terms (Fairchild \& MacKinnon, 2009). As shown by pair-wise correlation results displayed in 1, variable centering technique helped to mitigate severe multicollinearity problem between the primary variables and moderated variables. Table 4 shows the correlation coefficient matrix of both the primary and moderated variables. 
Table 4. Pairwise Correlation Matrix Results.

\begin{tabular}{|c|c|c|c|c|c|c|c|c|}
\hline & TD & LTD & STD & $\mathbf{S Z}$ & $\mathrm{TD} * \mathrm{SZ}$ & LTD $* S Z$ & STD*SZ & Z-Score \\
\hline TD & 1 & & & & & & & \\
\hline LTD & $-0.1759 *$ & 1 & & & & & & \\
\hline STD & $0.1759^{*}$ & $-1.0000^{*}$ & 1 & & & & & \\
\hline SZ & $0.3234 *$ & 0.0845 & -0.0845 & 1 & & & & \\
\hline $\mathrm{TD} * \mathrm{SZ}$ & -0.0118 & $0.2442 *$ & $-0.2442 *$ & 0.0449 & 1 & & & \\
\hline LTD*SZ & $0.2280^{*}$ & -0.0861 & 0.0861 & $0.2541^{*}$ & $-0.1163^{*}$ & 1 & & \\
\hline STD*SZ & $-0.2280^{*}$ & 0.0861 & -0.0861 & $-0.2541 *$ & $0.1163^{*}$ & -1 & 1 & \\
\hline Z-Score & $-0.8095^{*}$ & 0.0221 & -0.0221 & $-0.3133^{*}$ & $0.1698 *$ & $-0.1948 *$ & $0.1948 *$ & 1 \\
\hline
\end{tabular}

The asterisk * signify significance at $5 \%$ level

Table 4 shows that the pairwise correlation coefficients between all independent variables were less than 0.8 implying that the variables did not exhibit severe multicollinearity as recommended by (Gujarati, 2003). The perfect negative correlation coefficient between long term debt and short term debt variables (-1.000) indicated severe multicollinearity problem. To deal with this problem, the study dropped each of the highly collinear variable alternately while running the panel regression analysis as recommended by (Gujarati, 2003).

\subsection{Panel Model Regression Results}

In order to establish which panel effects (between fixed and random) provided better estimation results for the study, Hausman test was carried out for the specified panel regression model. The test was conducted against the null hypothesis that random effect model was the preferred model. The Hausman test results provided a chi-square value of 6.87 and a corresponding p-value of 0.0761 . The result indicated that the chi-square statistic was significant at $5 \%$ level. Effectively, the study rejected the null hypothesis that random effects model was appropriate and estimated the panel regression model for fixed effects as recommended by (Torres-Reyna, 2007).

Table 5. FGLS Fixed effects Panel Regression Results (for primary effects).

\begin{tabular}{lll}
\hline \multicolumn{3}{l}{ Dependent Variable: Financial Distress } \\
\hline Variable & Equation 1a & Equation 1b \\
\hline Constant & $12.7147^{*}(0.000)$ & $13.2403^{*}(0.000)$ \\
Total debt & $-12.6697^{*}(0.000)$ & $-12.6697^{*}(0.000)$ \\
Long term debt & $0.5256(0.312)$ & \\
Short term debt & & $-0.5256(0.312)$ \\
Size & $0.0421(0.748)$ & $0.0421(0.748)$ \\
Statistics & & \\
Adjusted $\mathrm{R}^{2}$ & 0.6354 & 0.6354 \\
Rho & 0.6521 & 0.6521 \\
Wald Chi ${ }^{2}(3)$ & 103.05 & 103.05 \\
Prob.(Wald) & 0.0000 & 0.0000 \\
Observations & 367 & 367 \\
\hline
\end{tabular}

* Signified significance at $5 \%$ level
Table 6. FGLS Fixed effects Panel Regression Results (for Moderated effects).

\begin{tabular}{|c|c|c|}
\hline \multicolumn{3}{|c|}{ Dependent Variable: Financial Distress } \\
\hline Variable & Equation 2a & Equation $2 \mathbf{b}$ \\
\hline Constant & $13.7452 *(0.000)$ & $14.5763 *(0.000)$ \\
\hline Total debt & $-12.9328 *(0.000)$ & $-12.9328 *(0.000)$ \\
\hline Long term debt & $0.8310(0.108)$ & \\
\hline Short term debt & & $-0.8310(0.108)$ \\
\hline Total debt*SZ & $1.3105 *(0.000)$ & $1.3105 *(0.000)$ \\
\hline Long term debt*SZ & $0.8329 *(0.002)$ & \\
\hline Short term debt*SZ & & $-0.8329 *(0.002)$ \\
\hline Size & $-0.03545(0.788)$ & $-0.03545(0.788)$ \\
\hline \multicolumn{3}{|l|}{ Statistics } \\
\hline Adjusted $\mathrm{R}^{2}$ & 0.6308 & 0.6308 \\
\hline Rho & 0.6767 & 0.6767 \\
\hline Wald $\mathrm{Chi}^{2}(3)$ & 73.05 & 73.05 \\
\hline Prob.(Wald) & 0.0000 & 0.0000 \\
\hline Observations & 367 & 367 \\
\hline
\end{tabular}

* Signified significance at 5\% level

Table 5 shows the results of panel regression model 1 estimated under equations $1 \mathrm{a}$ and $1 \mathrm{~b}$ for fixed effects with financial distress being the dependent variable and total debt, long term debt, short term debt and firm size as the independent variables. The model sought to derive the primary effect of capital structure on financial distress of non-financial firms. The results show the model had a coefficient of determination (R-squared) equivalent to 0.6308 and signifying that the fitted explanatory variables explained up to $63.08 \%$ of the variations in dependent variable. The Wald Chi-square statistic of 103.05 together with the corresponding p-values of 0.0000 indicated that the explanatory variables were jointly statistically significant at $5 \%$ significant level.

The results displayed on Table 5 further shows that the coefficient of total debt was negative and significant at 5\% level. The finding signified that highly indebted firms are generally financially distressed. The results further showed that the coefficients of long term and short term debts were not significant at 5\% level; meaning that debt maturity has no effect on financial distress. Table 5 also showed that though the coefficient of firm size is positive, it remained insignificant at 5\%. This implies that firm size didn't 
generally play a significant role in determining the direction of financial distress of non-financial firms.

However, looking at Table 6 , interesting results can be derived after introducing the interaction between capital structure and firm size components. First, it can be deduced that the coefficients of total debt*SZ is positive and significant at 5\% level. This means that increasing debt capital among large-sized firms actually improves their zscore value and hence makes them financially sound. The finding implies that firm size has a significant antagonizing moderating effect on the relationship between capital structure and financial distress. The result is in tandem with the studies by Ozgulbas et al. (2006) and Mule et al. (2015) both of whom found that large firms are generally favored by debt financing as a result of their expansive production capacity. This finding is however in contrast with that by Serrasqueiro and Nunes (2008) who found that large firms have high debt appetite due to high collaterization which lead to decline in performance.

The results further shows that the coefficients of the interaction variables between debt maturity (long term and short term debt) and size are significant at 5\% level. Specifically, the results indicate that employment of high levels of long term debt is improves the financial distress status among large-scale firms unlike smaller firms. The case is opposite where short term debt is involved. This finding is in consonance with that by Jónsson (2008) who argued that large firms can negotiate lower interest rates on long term debt and hence improve their overall performance. It is however at variance with the finding by Lee (2009) whose study averred that debt maturity has no effect on corporate financial distress.

\section{Summary, Conclusion \& Recommendations}

The study found that debt generally increases the incidence of financial distress among non-financial firms. However, firm size has a significant moderating effect on this relationship. The implication is that large scale firms are capable to employ high levels of debt and improve their financial distress status. The study also found that debt maturity as measured by the duration that debt remains outstanding has no significant effect on financial distress of non-financial firms. However, this situation is altered significantly upon considering firms of different sizes. Specifically, the study found that large firms can effectively employ large portfolios of long term debt and actually improve their distress status unlike smaller firms. The effect would however be opposite by employing short term debt. Based on these findings, the study concludes that firm size has a significant moderating effect on the relationship between capital structure and financial distress of nonfinancial firms listed in Kenya.

Based on the empirical findings from the study, the researchers makes a number of recommendations at firm level. Firstly, finance managers of non-financial firms should take into consideration the magnitude of their firms in making leverage choices. Particularly, firms with large assets portfolio may employ debt financing to a larger extent in comparison to smaller firms. This derives from the fact that debt financing is observed to be good for larger firms. Secondly, in making the choice on debt maturation, larger firms should prioritize the long term debts to short term debt. This is because long term debt is observed to be favorable in mitigating the effects of financial distress to larger firms.

This study was undertaken within the Kenyan context which is an emerging market. A similar study could be undertaken in the context of developed countries. Further, a similar study involving firms listed within financial sector such as banks and insurance firms could also be undertaken.

\section{References}

[1] Altman, E. I. (2000). Predicting financial distress of companies: revisiting the Z-score and ZETA models. Stern School of Business, New York University, 9-12.

[2] Amato, L. H., \& Burson, T. E. (2007). The effects of firm size on profit rates in the financial services. Journal of Economics and Economic Education Research, 8 (1), 67.

[3] Andrade, G., \& Kaplan, S. N. (1998). How costly is financial (not economic) distress? Evidence from highly leveraged transactions that became distressed. The Journal of Finance, 53 (5), 1443-1493.

[4] Artikis, G. P., Eriotis, N., Vasiliou, D., \& VentouraNeokosmidi, Z. (2007). How firm characteristics affect capital structure: An empirical study. Managerial Finance, 33 (5), 321-331.

[5] Babalola, Y. A. (2013). The effect of firm size on firms profitability in Nigeria. Journal of Economics and Sustainable Development, 4 (5), 90-94.

[6] Baimwera, B., \& Muriuki, A. (2014). Analysis of corporate financial distress determinants: A survey of non-financial firms listed in the NSE. International Journal of Current Business and Social Sciences, 1 (2), 58-80.

[7] Baltagi, B. H., Bratberg, E., \& Holmås, T. H. (2005). A panel data study of physicians' labor supply: The case of Norway. Health Economics, 14 (10), 1035-1045.

[8] Chen, J. J. (2004). Determinants of capital structure of Chinese-listed companies. Journal of Business Research, 57 (12), 1341-1351.

[9] Dittmar, A. (2004). Capital structure in corporate spin - offs. The Journal of Business, 77 (1), 9-43.

[10] Fairchild, A. J., \& MacKinnon, D. P. (2009). A general model for testing mediation and moderation effects. Prevention Science, 10 (2), 87-99.

[11] Gonenc, H. (2005). Comparison of debt financing between international and domestic firms: Evidence from Turkey, Germany and UK. International Journal of Managerial Finance, 1 (1), 49-68. 
[12] Granger, C. W., \& Newbold, P. (1974). Spurious regressions in econometrics. Journal of Econometrics, 2 (2), 111-120.

[13] Gujarati, D. (2003). Basic Econometrics (4 Edition). New Delhi, DN: McGraw Hill.

[14] Gupta, P., Srivastava, A., \& Sharma, D. (2014). Capital structure and financial performance: Evidence from India. International Research Journal, 2 (6), 112-126.

[15] Jónsson, B. (2008). Does the size matter? The relationship between size and profitability of Icelandic firms. Bifröst Journal of Social Science, 1 (6), 113-124.

[16] Khan, A. G. (2012). The relationship of capital structure decisions with firm performance: A study of the engineering sector of Pakistan. International Journal of Accounting and Financial Reporting, 2 (1), 245 - 262.

[17] Lee, J. (2009). Does size matter in firm performance? Evidence from US public firms. International Journal of the Economics of Business, 16 (2), 189-203.

[18] Maina, L., \& Ishmail, M. (2014). Capital structure and financial performance in Kenya: Evidence from firms listed at the Nairobi Securities Exchange. International Journal of Social Sciences and Entrepreneurship, 1 (11), 209-223.

[19] Marsh, P. (1982). The choice between equity and debt: An empirical study. The Journal of Finance, 37 (1), 121-144.

[20] Mugenda, \& Mugenda. (2003). Research methods quantitative and qualitative approaches. Nairobi, Kenya: African Center for Technology Studies.

[21] Muigai, R. G. (2016). Effect of Capital Structure on Financial Distress of Non-Financial Companies Listed in Nairobi Securities Exchange. COHRED, Finance, JKUAT.

[22] Mule, R. K., Mukras, M. S., \& Nzioka, O. M. (2015). Corporate size, profitability and market value: An econometric panel analysis of listed firms in Kenya. European Scientific Journal, 11 (13), 376 - 396.

[23] Mwangi, Muathe, S., \& Kosimbei, G. (2014). Relationship between capital structure and performance of non-financial companies listed in the Nairobi Securities Exchange, Kenya. Global Journal of Contemporary Research in Accounting, Auditing and Business Ethics, 1 (2), 72-90.

[24] Ohlson, J. A. (1980). Financial ratios and the probabilistic prediction of bankruptcy. Journal of Accounting Research, 1 (1), 109-131.

[25] Outecheva, N. (2007). Corporate financial distress: An empirical analysis of distress risk. Doctoral dissertation, University of St. Gallen, Switzerland.

[26] Ozgulbas, N., Koyuncugil, A., \& Yilmaz, F. (2006). Identifying the effect of firm size on financial performance of SMEs. The Business Review, Cambridge, 6 (1), 162-167.

[27] Pandey, I. M. (2009). Essentials of Financial Management $\left(1^{\text {st }}\right.$ Edition). New Delhi: DN, Vikas Publishing House Ltd.

[28] Papadogonas, T. A. (2006). The financial performance of large and small firms: Evidence from Greece. International Journal of Financial Services Management, 2 (2), 14-20.

[29] Papadogonas, T. A. (2006). The financial performance of large and small firms: evidence from Greece. International Journal of Financial Services Management, 2 (1-2), 14-20.

[30] Saunders, M. L., \& Lewis, P. and Thornhill, A. (2009), Research Methods for Business Students. London: UK, Financial Times Prentice Hall Inc.

[31] Serrasqueiro, Z. S., \& Nunes, P. M. (2008). Performance and size: empirical evidence from Portuguese SMEs. Small Business Economics, 31 (2), 195-217.

[32] Surajit, B., \& Saxena, A. (2009). Does the Firm Size Matter? An Empirical Enquiry into the Performance of Indian Manufacturing Firms. SSRN.[Online]. Available at: http://ssrn. com/abstract, 1300293.

[33] Torres-Reyna, O. (2007). Panel data analysis fixed and random effects using Stata (v. 4.2). Data \& Statistical Services, Princeton University.

[34] Velnampy, T. (2013). Corporate governance and firm performance: a study of Sri Lankan manufacturing companies. Journal of Economics and Sustainable Development, 4 (3), 228-235.

[35] Vijayakumar, A., \& Tamizhselvan, P. (2010). Corporate size and profitability: An empirical analysis. Journal for Bloomers of Research, 3 (1), 44-53.

[36] Wiggins, V., \& Poi, B. (2001). How do I test for panel-level heteroskedasticity (5th Ed). Italy: Prentice Hall. 